UDC 658.8

S. V. Kovalchuk, Dr. Sc. (Econ.), Prof., orcid.org/0000-0001-9535-8678,

D. L. Kobets, Cand. Sc. (Econ.), Assoc. Prof., orcid.org/0000-0002-4822-2951,

Ye. M.Zaburmekha, Cand. Sc. (Econ.), Assoc. Prof., orcid.org/0000-0003-2223-3887

\title{
MODELING THE CHOICE OF STRATEGIES OF MARKETING MANAGEMENT OF ENTERPRISE PERSONNEL
}

Purpose. Consideration of theoretical and scientific-methodical concepts and development of practical recommendations on formation of economic and mathematical model of mutual positioning of strategies of marketing and personnel management.

Methodology. Methods of analysis, synthesis, generalization, comparison and mathematical modeling are used.

Findings. The embodiment of the economic and mathematical model is the matrix of mutual positioning of strategies of marketing and personnel management. The matrix is an effective tool of acceptance of adequate managerial decisions for achievement of desired result (economical, marketing, managerial, social, and household). At the same time, mathematical problem solving enables one to simplify process itself of acceptance of managerial decisions at option of marketing strategy of personnel management which is adequate to framework conditions, state of external and internal environment of the enterprise.

Originality. A complex approach to formation of marketing strategy of personnel management in view of the common and specific principles, aimed at realization of purposes and the tasks of personnel management is developed. For implementation of the offered approach, an economic and mathematical model of mutual positioning of strategies of marketing and personnel management is developed and approved by the example of enterprises of the mechanical engineering sector of Ukraine.

Practical value. The results obtained during the practical approval confirmed adequacy of the economic and mathematical model and expediency of its application, which is reflected in the appropriate economic benefit. At the enterprises which applied the offered approach optimization of the process of monitoring in marketing and personnel policy is observed at the expense of elimination of duplicating information flows.

Keywords: marketing strategy, system approach, personnel management, machine-building enterprises

Introduction. Transformational changes which are defined by economical, technological, public-political and internal conditions require quick response on the part of managing subjects. Respectively, it is possible to raise efficiency of such response through introduction of the conception of holistic marketing, during realization of which scientists try to unite four kinds of marketing (social and ethic responsible one; integrated one; relationship marketing and internal marketing). This approach provides orienteers to a customer as the universal principle of activity of all services and divisions of an enterprise; integral and long-term development of marketing approaches in control.

Development of modern enterprises should be considered exactly from the positions of holistic marketing, as it enables to solve tasks in view, using modern market technologies, to predict an enterprise's activities, taking into account factors of framework conditions. Along with that, the object of marketing impact involves all key competence of the enterprise, to which personnel management relates as well. In fact, effective functioning of the enterprise and formation of the bases of its steady situation in remote perspective is defined by an adequate strategy of use and development of the personnel. This strategy is one of the most important tools of implementation of the main functions of system control. Forma-

(C) Kovalchuk S. V., Kobets D. L., Zaburmekha Ye. M., 2019 tion of such approach is impossible without co-ordination of purposes, activities of marketing and control of human resources.

Insufficient scientific development of separate aspects and high practical importance of introduction of marketing strategies of personnel management to activity of enterprises of the mechanical engineering sector and using of methods of economic and mathematical simulation confirm relevance of this problem.

Analysis of the recent research and publications. In literature, a large amount of works, devoted to personnel management can be allocated. Leading scientific economists wonder what the personnel management is - necessity or new flow in business [1]. Research studies are called to grasp the importance of the strategy of personnel management from the standpoint of its proper designing and realization. At the same time opportunity of the optimization of this process with the aid of economic and mathematical simulation is not determined.

A number of scientists investigate opportunities of engagement of external specialists to work of an enterprise [2]. In the work, mathematical simulation of output of human resources and expenditures which occur is performed. Research studies give grounds for solving the problem of supplying the coherence between effective expenditures to human resources, providing of high motivation and increase in efficiency of use of human re- 
sources. However, they do not solve the problem of coordination of the marketing strategy with an enterprise's personnel strategy.

Significant contribution to the development of scientific approaches to the personnel management strategy was made by the representatives of Welsh school of business management, who investigated influence of personnel management on realization of an enterprise's marketing strategy [3, 4]. The authors offer a conceptual model, which is based on the principles of effective marketing and interaction with personnel and is a result of successful implementation of the marketing strategy. But these research studies are in the plane of formation of the personnel marketing and do not give answers to question of optimization of making managerial decisions.

Some scientists attempt to compare the strategy of personnel management with a company's marketing strategy [5]. In the work, purposes and functions of both strategies are considered, particular application examples are provided, Other scientists they conduct research in this direction as well [6]. They search for answer to the question of influences of alignment of the businessstrategy and HR-strategy on efficiency of the enterprise activities. We believe that efficiency of the enterprise activity, in particular, depends on efficiency of managerial decisions in the area of marketing and personnel management; however, this particular aspect is not covered enough in specified works.

Certain scientists offer a methodical approach to development of the strategy of personnel management on the basis of marketing and perform the evaluations of chemical enterprises by the offered technique [7]. Doubts arise in universal nature of the offered approach and opportunity of its application for the enterprises of other branches of the economy; moreover, the approach did not go any further regarding the economic and mathematical simulation.

Thus, the identified issues emphasise the fact that system processes of globalized, institutional and information transformations are directed at meeting the needs of subjects of economic relations. First of all, this concerns innovative technological production, formation of competitive environment at engineering production markets. This is complexity of revealed problems in the field of strategic marketing personnel management, definition of human factor as the basis for making managerial decisions and their effective implementation, which requires their solving with the help of economic and mathematical methods and technologies.

Objectives of the article. The purpose of the research is consideration of theoretical and scientific-methodical situations and development of practical recommendations on formation of an economic and mathematical model of mutual positioning of strategies of marketing and personnel management. To achieve the target, the following tasks were solved:

- to generate a complex approach to marketing strategic personnel management on the basis of definition of real opportunities of realization of organizational development of machine-building enterprises;
- to define and to analyze influence of endogenic and exogenic factors on dynamics of social and economic indices of activity of machine-building enterprises regarding the personnel management using economic and mathematical toolkit;

- to develop a structural-logic model of marketing strategy of personnel management of machine-building enterprise as the precondition of application of scenario approach to management decision making.

Complex approach to formation of marketing strategy of enterprise personnel management. Efficiency of an enterprise's activities, which is provided by combination of its marketing and personnel selection in view of strategic perspectives, defines the enterprise's long-term competitiveness.

Strategic control can be considered as dynamic set of interconnected managerial processes, which logically follow from each other.

Formation of the strategy assumes definition of vision of the enterprise, strategy, organizational competence, plan of actions and realization. Choice of particular strategy is implemented, based on long-term objectives of the enterprise, internal resources and traditions (Fig. 1).

The marketing strategy of personnel management should provide an opportunity of realization of control on the basis of anticipating of changes, flexible prime decisions, making strategic decisions in the conditions of low certainty and changes. Formation, realization and realization of the marketing strategy of personnel management should take into account the directions of changes and be implemented with use of new managerial technologies.

Application of a complex approach to selection of a marketing strategy of personnel management (MSPM) assumes the consideration of framework conditions, marketing and internal environment which are selected based on the results of conducting appropriate marketing research studies. This enables the enterprise to implement personnel resources for creation of steady competitive advantages in the most effective way. Complexity of the approach is evident in step-by-step solution of tasks on formation and realization of the MSPM.

Tangible embodiment of the marketing strategy of personnel management is implemented on the basis of development of a strategic plan for one of four of the elected phases: formation; embodiments; stabilization; development. These phases include specific objectives and events on performance of the strategy, time frames and people in charge of each of the tasks, volume of necessary resources (financial, material, information and others).

Depending on which phase of activity the strategic plan is designed for, marketing toolkit on personnel management will have other filling.

Therefore, if a strategic plan is developed for formation of the MSPM, it is meant that the enterprise develops new directions of its activity or only begins its functioning on the market, implements diversification strategy, or invests funds into projects (directions) with high level of financial risks. This phase features inherent 


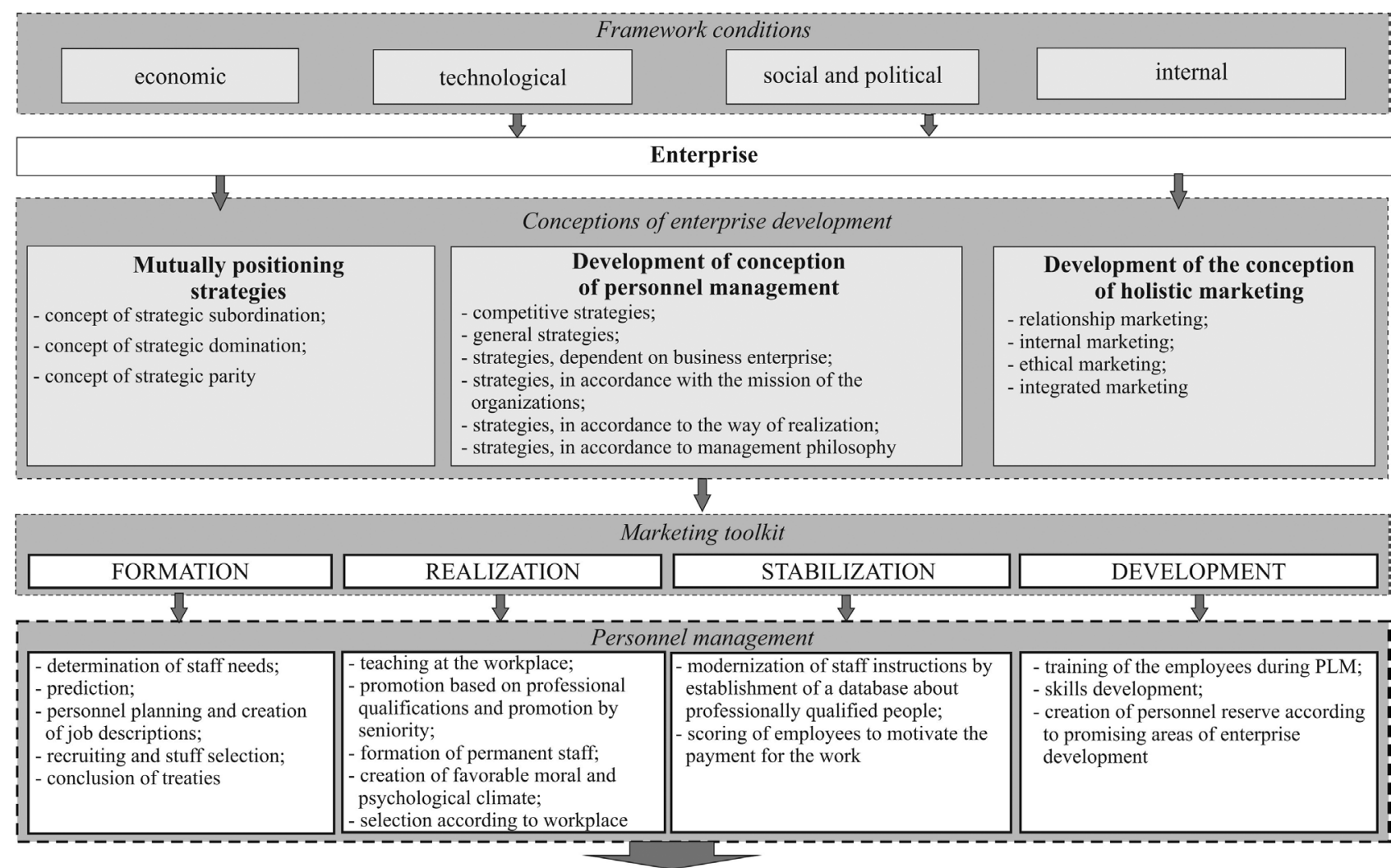

\section{MARKETING STRATEGY OF PERSONNEL MANAGEMENT}

\section{Fig. 1. Conceptual bases of formation of marketing strategy of personnel management}

corporate-wide business strategy, which requires development and realization of following tasks from the MSPM: providing the enterprise with innovative workers, capable of flexible thinking and quick adaptation.

The result of Implementation of the MSPM for this phase of the enterprise's development involves creation of favorable conditions for professional development of the person, career advancement. Efficiency of realization of this strategy is defined by evaluating individual and collective results of work.

For implementation phase, a base strategy of dynamical growth is relevant. This strategy aims at changing purposes and the structures of the enterprise to find balance between necessary changes and stability.

During the phase of stabilization, strategic planning of the MSPM is developed for enterprises which are at the stage of maturity and count on receiving constant income from realization of goods, which are in strong demand on the market; they require a stabilization strategy. Formation of strategic plans of the MSPM for this phase should take into account the fact that administration is concerned about increase in volumes of realization at minimization of expenditures. Control system is clearly formalized using methods of tough control, and, therefore, MSPM is based on maintaining the already reached level of workers' professional skills through continuous advanced vocational training.

The development phase provides two possible alternatives: either the enterprise changes over to a new grade, which will correspond to the "formation-embodiment" phase; or "stagnation-sanitation-elimina- tion" scenario is started. The last scenario is chosen by the enterprise, if almost all trends or mainstreams of the activities are unprofitable and goods, which are issued by the enterprise, are in little demand on the market, which, in turn, orients MSPM to social security of workers and increase in competitiveness on the job market in case of reduction of the number of the personnel.

Taking into account possible variants of interaction and subordination of corporate-wide, marketing (MR) strategies and the strategy of personnel management (PM), a structured system of strategy of marketing control of enterprises personnel is developed. This system is presented in Table 1 as a matrix of mutual positioning of strategies of marketing and personnel management of a machine-building enterprise.

The careful analysis of personnel management at machine-building enterprises of Khmelnytskyi area confirmed reasonableness of the fact that in order to increase efficiency of using the labor potential at specified enterprises, it is necessary to apply various scenarios at development of marketing strategy of personnel management. These scenarios would correspond maximally to the direction of activity of one or another enterprise and allow increasing the labor productivity level and supplying a proper level of the salary in the future.

The in-depth studies on condition and the level of personnel management at machine-building enterprises allow developing offers on formation of the marketing strategy of personnel management.

First, it is necessary to pay attention to implementation of personnel selection at each particular enter- 
The Matrix of mutual positioning of strategies of marketing and personnel management

\begin{tabular}{|l|l|l|l|}
\hline $\begin{array}{l}\text { Strategies of personnel } \\
\text { management(PM), } \\
\text { Strategy (MR), } \\
\text { Smr }\end{array}$ & $\begin{array}{l}\text { Subordination of the strategy of } \\
\text { PM to the enterprise-wide } \\
\text { strategy }\end{array}$ & $\begin{array}{c}\text { The equivalence of PM } \\
\text { strategy and the } \\
\text { enterprise-wide strategy }\end{array}$ & $\begin{array}{c}\text { PM strategy domination } \\
\text { above the enterprise-wide } \\
\text { strategy }\end{array}$ \\
\hline $\begin{array}{l}\text { Subordination of MR } \\
\text { strategy to the } \\
\text { enterprise-wide strategy }\end{array}$ & $\begin{array}{l}\text { The strategies of PM and MR } \\
\text { are equivalent and are subject of } \\
\text { the enterprise-wide strategy }\end{array}$ & $\begin{array}{l}\text { PM strategy is equivalent to } \\
\text { the corporate strategy of the } \\
\text { enterprise, marketing strategy } \\
\text { acts as a subordinate one }\end{array}$ & $\begin{array}{l}\text { The PM strategy dominates } \\
\text { the enterprise-wide strategy. } \\
\text { Definition of marketing and } \\
\text { enterprise-wide purposes is } \\
\text { implemented based on } \\
\text { strategic direction of } \\
\text { personnel management }\end{array}$ \\
\hline $\begin{array}{l}\text { The strategy equivalence of } \\
\text { MR and the enterprise-wide } \\
\text { strategy }\end{array}$ & $\begin{array}{l}\text { MR strategy is equivalent to the } \\
\text { corporate strategy of the } \\
\text { enterprise, PM strategy acts } \\
\text { as a subordinate one }\end{array}$ & $\begin{array}{l}\text { Depending on the market } \\
\text { and internal situation at the } \\
\text { enterprise, strategies' } \\
\text { interaction and } \\
\text { subordination can change }\end{array}$ & $\begin{array}{l}\text { PM dictates changes in the } \\
\text { marketing and the } \\
\text { enterprise-wide strategy }\end{array}$ \\
\hline $\begin{array}{l}\text { MR strategy domination } \\
\text { above the enterprise-wide } \\
\text { strategy }\end{array}$ & $\begin{array}{l}\text { MP strategy dominates above } \\
\text { the enterprise-wide strategy. } \\
\text { Definition of purposes of } \\
\text { personnel management and } \\
\text { enterprise-wide purposes is } \\
\text { implemented based on strategic } \\
\text { marketing direction }\end{array}$ & $\begin{array}{l}\text { MR dictates changes of the } \\
\text { PM strategy and the } \\
\text { enterprise-wide strategy }\end{array}$ & $\begin{array}{l}\text { Marketing strategy of } \\
\text { personnel management. } \\
\text { MSPM }\end{array}$ \\
\hline
\end{tabular}

prise. Analysis of the internal environment on definition of current condition of personnel control at machinebuilding enterprises showed modest professional standards and readiness to strategic changes (Table). Such a situation, on the one hand, is due to lack of psychologists and sociologists on the enterprise staff as well as to a low base educational level of the employees of enterprises and significant personnel ageing. On the other hand, at most enterprises, marketing approach to the recruiting process is lacking, not to mention application of the personnel marketing at enterprises.

Secondly, it is necessary to provide material and moral incentive of workers in the human resource management systems: promotion of the employee's rank or upgrading, establishing of premiums and increments connected with professional advancing and so on. Perfecting of the system of the organization of labor will allow revealing parallel functions of workers and taking measures on perfecting their work; strengthening interest of workers of all levels in their work. It will allow increasing overall profitability of the enterprise as a whole and raising living standards of workers in particular.

Thirdly, at formation of the marketing strategy of personnel management modern technologies should be necessarily used. So, new conditions of managing, dynamism and ambiguity of external conditions, increase in educational level of the personnel and changes in motivation of workers lead to development of organizational culture in all respects, including the development of marketing culture, and hereinafter - marketing business philosophy.

Therefore, taking into account possible alternativeness of choice of the marketing strategy of personnel management, we will conduct an economic and mathematical simulation of mutual positioning of strategies of marketing and personnel management of machinebuilding enterprises applying the matrix approach.

Results of simulation of mutual positioning of strategies of marketing and personnel management at the enterprises. Justification and choice of marketing strategies of personnel management essentially depends on the toolkit of marketing collateral of personnel management. This, primarily, is due to the fact that the enterprise personnel is considered as a strategic renewable resource, and, so its control is of top priority in the enterprise-wide strategy purposes.

For implementation of marketing strategies of personnel control, it is also necessary to introduce the conception of holistic marketing into machine-building enterprises' activities (and within their limits, internal marketing) for stimulation of personnel management of machine-building enterprises. Besides, in the context of formation of partnership relations, the strategy should be advanced according to the criterion of minimum terms of negotiations and maximum impact of partnership mutually advantageous communications, both outside, and inside the enterprise regarding the personnel. Formally it can be recorded as

$$
\begin{aligned}
& \min _{t_{\text {perem }}} M P_{\text {PartS }}\left(t_{\text {perem }}, k_{\text {inter }}\right) ; \\
& \max _{k_{\text {ther }}} M P_{\text {PartS }}\left(t_{\text {perem }}, k_{\text {inter }}\right),
\end{aligned}
$$

where $M P_{\text {Part }}$ is the rate of strategic marketing personnel management of enterprises in the context of for- 
mation of partnership relations within activities of machine-building enterprises; $t_{\text {perem }}$ is a general duration of the periods (terms) of negotiations between stakeholders; $k_{\text {inter }}$ is the rate of influence of partnership mutually advantageous communications on the rating of strategy of marketing control of enterprises' personnel $M P_{\text {Parts }}$.

Function $M P_{\text {Parts }}\left(t_{\text {perem }}, k_{\text {inter }}\right)$ within the signs of extremums in formulas $(1,2)$ should be rationed with reference to its arguments. It means that strict inequality should be satisfied

$$
0<M P_{\text {Part } S}\left(t_{\text {perem }}, k_{\text {inter }}\right)<1 .
$$

Ideal case of $M P_{\text {Parts }}\left(t_{\text {perem }}, k_{\text {inter }}\right)=1$, at which we receive $100 \%$ of strategic marketing personnel management of enterprises in the context of formation of partnership relations within machine-building enterprises' activities, is impossible. Such impossibility is merely due to the fact that natural competition and external limitations of the type of buying power of consumers, inflation processes, regulatory politics of the state, processes on the labor market and so on.

The worst case of $M P_{\text {Parts }}\left(t_{\text {perem }}, k_{\text {inter }}\right)=0$ is not considered. This case, on the one hand, corresponds to a total divergence of a machine-building enterprise (only operating enterprises participate in the research, where personnel management is implemented on constant base, which are on the "move", that is, $t_{\text {perem }}>0$ and $k_{\text {inter }}>0$ ). On the other hand, it corresponds to absolute ineffective attempts to generate partnership relations for application of holistic marketing (which appears alogical, since there are no "individual" enterprises in engineering simply).

As was noted above, the arguments of function $M P_{\text {Parts }}\left(t_{\text {perem }}, k_{\text {inter }}\right)$ are positive: $t_{\text {perem }}>0$ (a certain period of negotiations always exists) and $k_{\text {inter }}>0$ (influence of partnership mutually advantageous communications is always present). However, we will note that $k_{\text {inter }}=0.05$ or $k_{\text {inter }}=0.1$ should be the ratings of negative impact. Thus, let us normalize this rating: $k_{\text {inter }} \varepsilon(0 ; 1]$. Then cases $k_{\text {inter }} 0.5$ will be considered as those where influence of partnership mutually advantageous communications on strategizing of marketing personnel management of enterprises in the context of formation of partnership relations within activities of machine-building enterprise is negative (to a certain extent). At the approach to zero value this negative is maximum. At the approach to the value $k_{\text {inter }}=0.5$ negative influence is compensated almost entirely. Positive influence of partnership mutually advantageous communications is observed at $k_{\text {inter }}>0.5$.

On technicalities, there are two tasks $(1,2)$, however, they can be united to one minimax task

$$
\underset{t_{\text {perem }}}{\min k_{\text {ther }}} \operatorname{MPax} P_{\text {PartS }}\left(t_{\text {perem }}, k_{\text {inter }}\right) \text {. }
$$

At the same time the solution $\left(k_{3 \text { ther }}^{* *}, t_{\text {perem }}^{* *}\right)$ of maximum task is

$$
\operatorname{maxmin}_{k_{\text {stuer }} \operatorname{t}_{\text {perem }}} M P_{\text {PartS }}\left(t_{\text {perem }}, k_{\text {inter }}\right),
$$

it is always worse than the solution of minimax task (3) $\left(t_{\text {perem }}^{*}, k_{\text {inter }}^{*}\right)$, if function $M P_{\text {Part }}\left(t_{\text {perem }}, k_{\text {inter }}\right)$ does not have a saddle point (presence of a saddle point is rather unusual occurrence). It is commonly known that

$$
\begin{aligned}
& \operatorname{maxmin}_{k_{\text {inter }} t_{\text {perem }}} M P_{\text {Parts }}\left(t_{\text {perem }}, k_{\text {inter }}\right) \leq \\
& \leq \operatorname{minm}_{t_{\text {perem }}} k_{\text {iner }} \\
& P_{\text {Parts }}\left(t_{\text {perem }}, k_{\text {inter }}\right),
\end{aligned}
$$

is performed for any functions $M P_{\text {Parts }}\left(t_{\text {perem }}, k_{\text {inter }}\right)$, and equality

$$
\begin{aligned}
& \operatorname{maxmin}_{k_{\text {ther }} t_{\text {perem }}} M P_{\text {PartS }}\left(t_{\text {perem }}, k_{\text {inter }}\right)= \\
& =\min _{t_{\text {perem }}} k_{\text {ther }} \operatorname{Max} P_{\text {PartS }}\left(t_{\text {perem }}, k_{\text {inter }}\right) \text {, }
\end{aligned}
$$

takes place only for those functions $M P_{\text {Part }}\left(t_{\text {perem }}, k_{\text {inter }}\right)$, which have a saddle point (one or more). Hence, it follows that it is better to solve the problem (3), solution $\left(t_{\text {perem }}^{*}, k_{\text {inter }}^{*}\right)$ of which will give the value of the rating strategy of marketing personnel management of enterprises in the context of formation of partnership relations in activities of machine-building enterprises, it is not worse than the value for junction $\left(t_{\text {perem }}^{*}, k_{\text {inter }}^{*}\right)$

$$
M P_{\text {Part } S}\left(t_{\text {perem }}^{* *}, k_{\text {inter }}^{* *}\right) \leq M P_{\text {Parts }}\left(t_{\text {perem }}^{*}, k_{\text {inter }}^{*}\right) .
$$

Certainly, in most instances when function $M P_{\text {Parts }}\left(t_{\text {perem }}, k_{\text {inter }}\right)$ does not have a saddle point, and consequently, inequality (8) will be strict

$$
M P_{\text {Part }}\left(t_{\text {perem }}^{* *}, k_{\text {inter }}^{* *}\right)<M P_{\text {Parts }}\left(t_{\text {perem }}^{*}, k_{\text {inter }}^{*}\right),
$$

which unambiguously confirms preference to exactly the solution $\left(t_{\text {perem }}^{*}, k_{\text {inter }}^{*}\right)$ of the minimax task (4).

Discussion of results on simulation of mutual positioning of strategies of marketing and personnel management. Optimum marketing provision of the process of formation of partnership relations in a machine-building enterprise's activities is the base for strategizing marketing control of its personnel. Such system includes, apart from enterprise-wide strategy, the strategy of personnel management and marketing strategy. This group of strategies is in certain correlation, which is defined by how the groups of strategies of personnel control and marketing strategies are subordinated regarding to enterprise-wide strategy. However, they can dominate it. Moreover, interaction and subordination can be changed depending on framework conditions, external marketing environment and internal situation at the enterprise.

We will consider sequence of formation of economic and mathematical model regarding the strategizing the marketing personnel management of enterprises according to the constructed matrix of mutual positioning of strategies of marketing and personnel management of a machine-building enterprise (Table).

In the previous research studies while choosing an optimum marketing structure of the enterprise [8], Kemeni-Snell's median for matrixes ranking was used. In this instance the specified approach cannot be applied at once, as mutual positioning of strategies takes place, in- 
stead of simply ranking. It is necessary to carry out a series of transformations for reduction of mathematical model to the necessary type.

The elements of the matrix of mutual positioning of strategies of personnel management and marketing strategy are both processes of interaction of these strategies with the enterprise-wide strategy, and the result of such interaction. Manufacturing of any out of nine processes of interaction in the matrix of mutual positioning in Table is a functional transition of the type

$$
M S P M=F\left(S_{P M}, S_{M R}, Z_{\text {Corp }}\right),
$$

where $S_{P M}$ is the strategy of personnel management from plenty of all possible strategies of personnel management $A_{P M}$, and this collection is finite, that is, choice $S_{P M} \in S_{P M}$ is executed over a residual period; $S_{M R}$ is the strategy of marketing from plenty of all possible strategies of marketing $A_{M R}$, and this collection is finite as well, and choice $S_{M R} \in A_{M R}$ is made for over a residual period; $Z_{C o r p}$ is a certain enterprise-wide strategy from infinite set of all such strategies $A_{\text {Corp }}$ possible, therefore choice $Z_{\text {Corp }} \in Z_{\text {Corp }}$ is made on the basis of results of enterprise-wide meetings and consultations; $M_{S P M}$ is a marketing strategy of personnel management which depends on multitude $A_{P M} \times A_{M R} \times A_{\text {Corp }}$.

Applying transitions transition (5) results in such marketing strategy of personnel management that allows using a personnel potential of the enterprise to maximum effect. Due to domination of strategies of personnel management and marketing strategy, the enterprise-wide strategy is chosen not simultaneously, but consistently for them, after that development of marketing strategies of personnel management follows. Functional transition of the type (5) is built on the basis of expert evaluations. We at first define fullness of the multitude of all possible strategies of personnel management $A_{U P}$, marketing $A_{M R}$, enterprise-wide strategies $A_{C o r p}$. It is executed by skilled marketing analysts (multitudes $A_{M R}$ and $A_{C o r p}$ ), trained managers (multitude $\mathrm{A}_{\mathrm{PM}}$ ). Further, the multitude $A_{P M} \times A_{M R} \times$ $A_{\text {Corp }}$ is defined automatically, each element of which corresponds to a certain marketing strategy of personnel management.

Let

$$
\left|A_{P M} \times A_{M R} \times A_{\text {Corp }}\right|=N_{M S P M},
$$

that is multitude of all possible marketing strategies of personnel management consists of $N_{M S P M}$ strategies (variants). We will designate such $\mathrm{n}$ variant through $\mathrm{v}_{M S P M}(n)$, where $n=\overline{1, N_{M S P M}}$. Then, it is necessary to enter $N_{M S P M} \times N_{M S P M}$ the matrixes of pairwise comparisons for consideration. For the $j^{\text {th }}$ expert we will designate such matrix through

$$
\mathbf{Q}_{j}=\left[a_{n k}(j)\right]_{N_{M S P M} \times N_{M S P M}},
$$

where $a_{n k}(j)$ is the value of the element of the matrix of pairwise comparisons, which is at the intersection of $n^{\text {th }}$ line and $k^{\text {th }}$ column (exactly according to the opinion of $j^{\text {th }}$ expert).
If $W$ experts are involved in the evaluation procedures in total, then we will receive $W$ matrixes of pair comparisons

$$
\left\{\mathbf{Q}_{j}=\left[a_{n k}(j)\right]_{N_{M S P M} \times N_{M S P M}}\right\}_{j=1}^{W} .
$$

Specified matrixes are positive back-symmetric. It should be noted that experts, while constituting matrixes (6), should adhere such properties of back-symmetric matrixes as:

1) invertibility property, by which $a_{n k}(j)=\frac{1}{a_{k n}(j)}$ on $n=\overline{1, N_{M S P M}}$ and $k=\overline{1, N_{M S P M}}$ for all $j=\overline{1, W}$;

2) property of single main diagonal, by which

$$
a_{n n}(j)=1 \quad \text { when } n=\overline{1, N_{M S P M}} .
$$

As it was already noted, the elements of the matrixes of pair comparisons are positive numbers. According to the standards of method of analysis of hierarchies regarding the values of elements of the matrix of pairwise comparisons, each expert gives only such an expert opinion which is a congruum or a fractional number. At the same time standardized scale is used [9]

$$
a_{n k}(j) \in\left\{\frac{1}{9}, \frac{1}{8}, \frac{1}{7}, \frac{1}{6}, \frac{1}{5}, \frac{1}{4}, \frac{1}{3}, \frac{1}{2}, 1,2,3,4,5,6,7,8,9\right\},
$$

when

$$
n=\overline{1, N_{M S P M}} \text { and } k=\overline{1, N_{M S P M}} \text { for all } j=\overline{1, W} \text {. }
$$

Therefore, the expert chooses among 17 variants of the evaluations of opinions. Motivation for choice involves the following prescripts to correlations $n^{\text {th }}$ and $k^{\text {th }}$ marketing strategies of personnel management [10]:

1. The value of the element $a_{n k}(j)$ of the matrix of pairwise comparisons $\mathbf{Q}_{j}$ is taken to be equal to 1 , if $n^{\text {th }}$ and $k^{\text {th }}$ marketing strategies of personnel management are equivalent (equivalent or have identical influence) then

$$
a_{k n}(j)=a_{n k}(j)=1 \text {. }
$$

2. The value of the element $a_{n k}(j)$ of the matrix of pairwise comparisons $\mathbf{Q}_{j}$ is taken to be equal to 3 , if $n^{\text {th }}$ marketing strategy of personnel management is more useful, than $k^{\text {th }}$ strategy, but this advantage in utility is insignificant (besides, only according to the opinion of $j^{\text {th }}$ expert) then

$$
a_{k n}(j)=\frac{1}{3} ; \quad a_{n k}(j)=3 .
$$

3. The value of the element $a_{n k}(j)$ of the matrix of pairwise comparisons $Q_{j}$ is taken to be equal to 5 , if $n^{\text {th }}$ marketing strategy of personnel management is more useful, than $k^{\text {th }}$ strategy, and this advantage in utility is significant; then

$$
a_{k n}(j)=\frac{1}{5} ; \quad a_{n k}(j)=5 .
$$


Identification of enterprise-wise list and marketing strategies, which correspond to functional tasks

of personnel management strategy and are allowable for the investigated enterprise

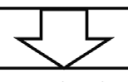

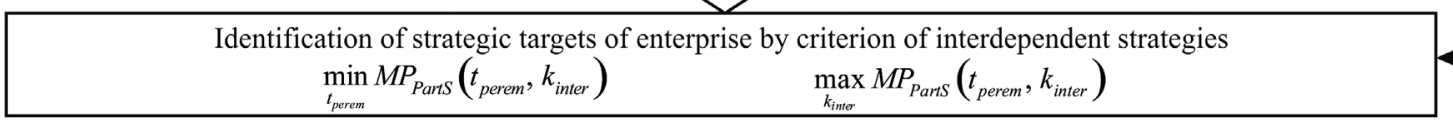

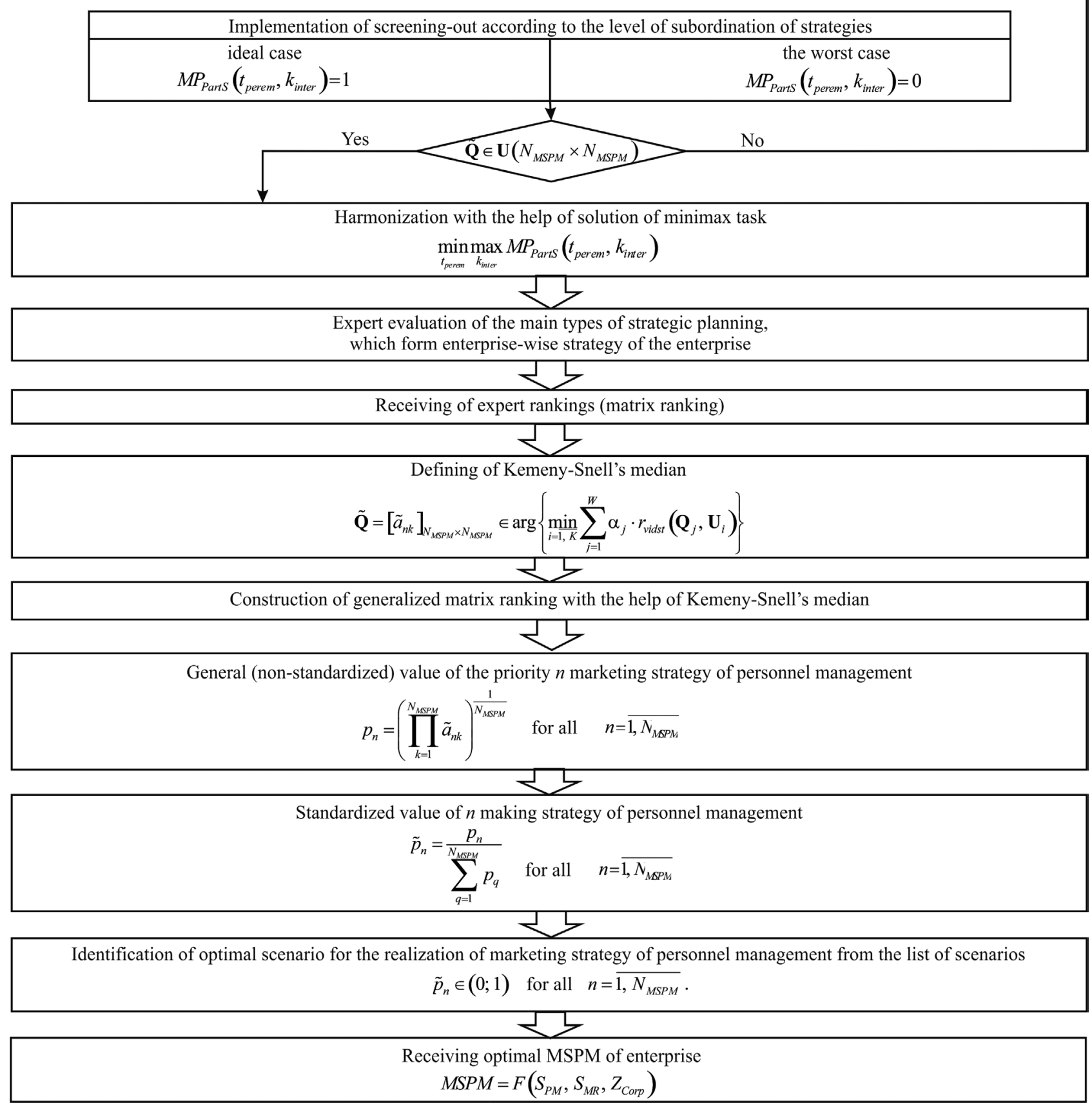

Fig. 2. Algorithm of selection of optimum marketing strategy of personnel management

4. The value of the element $a_{n k}(j)$ of the matrix of pairwise comparisons $Q j$ is taken to be equal to 7, if $n^{\text {th }}$ marketing strategy of personnel management is much more useful, than $k^{\text {th }}$ strategy, then

$$
a_{k n}(j)=\frac{1}{7} ; \quad a_{n k}(j)=7
$$

5. The value of the element $a_{n k}(j)$ of the matrix of pairwise comparisons $Q j$ is taken to be equal to 9 , if $n^{\text {th }}$ marketing strategy of personnel management prevails absolutely $k^{\text {th }}$ strategy on utility, then

$$
a_{k n}(j)=\frac{1}{9} ; \quad a_{n k}(j)=9 .
$$


Experts know that integers 1, 3, 5, 7, 9 and their reciprocal variables on scale (7) are the main numerical evaluations of expert opinions. Experts are also informed that they have the right to use integers $2,4,6,8$ and their reciprocal variables for facilitation of compromises between their opinions which can often be different from opinions which relate to the integers 1, 3, 5, 7, 9 and their reciprocal variables.

When the matrixes (6) are available, that is, all expert procedures of the evaluation are carried out, there comes the next task - construction of averaged matrix of pairwise comparisons Let us note that this matrix should not necessarily be one of the matrixes in the set (6). In fact, an averaged matrix of pairwise comparisons is chosen by optimum way from plenty of all positive backsymmetric matrixes of the format $N_{M S P M} \times N_{M S P M}$, the values of elements of which lie within the scale (7). We will designate this multitude through $\mathbf{U}\left(N_{M S P M} \times N_{M S P M}\right)$. So, it is necessary to make a choice

$$
\tilde{\mathbf{Q}} \in U\left(N_{M S P M} \times N_{M S P M}\right),
$$

by a certain criterion of the optimality.

Choice (8) is made with use of the technique offered in works [9-11]. At first, weighted distances between the experts' matrixes $\left\{\mathbf{Q}_{j}\right\}_{j=1}^{W}$ and matrixes from multitude $\mathbf{U}\left(N_{M S P M} \times N_{M S P M}\right)$ are found. We will note that the amount of such matrixes depends only on the rating scale. For our case, we will designate the number of matrixes in the multitude $\mathrm{U}\left(N_{M S P M} \times N_{M S P M}\right)$ through $K$.

So, let

$$
\mathbf{U}\left(N_{M S P M} \times N_{M S P M}\right)=\left\{\mathbf{U}_{i}\right\}_{i=1}^{K},
$$

where

$$
\mathbf{U}_{i}=\left[u_{n k}(i)\right]_{N_{M S U P} \times N_{M S U P}}
$$

Then distance between matrixes $Q j$ (opinions of the $j^{\text {th }}$ expert) and $U i$ is calculated in the following way [10]

$$
r_{\text {vidst }}\left(Q_{j}, U_{i}\right)=\sqrt{\sum_{n=1}^{N_{\text {MSPM }}-1}\left(\sum_{k=n+1}^{N_{M S P M}}\left(1+\left[a_{n k}(j) u_{n k}(i)\right]^{2}\right) \cdot \frac{\left[a_{n k}(j)-u_{n k}(i)\right]^{2}}{\left[a_{n k}(j) u_{n k}(i)\right]^{2}}\right.}
$$

for all $j=\overline{1, W}$ and $i=\overline{1, K}$.

While calculating distances (9), we remember that

$$
r_{\text {vidst }}\left(\mathbf{Q}_{j}, \mathbf{U}_{i}\right)=r_{\text {vidst }}\left(\mathbf{U}_{i}, \mathbf{Q}_{j}\right)
$$

and

$$
r_{\text {vidst }}\left(\mathbf{Q}_{j}, \mathbf{Q}_{j}\right)=0 \text {. }
$$

Application of such approach will diminish the number of necessary calculations considerably and will speed up the process of formation of marketing strategy of personnel management. At small multitudes of admissible strategies of personnel management, the strategies of marketing and enterprise-wide strategies, such acceleration will not be noticeable. However, most machinebuilding enterprises feature wide choice of specified strategies; therefore, in such cases reduction of calculations will appear to be surprisingly profitable for acceleration of formation of marketing control strategy.

Thus, the task (8) is solved with minimisation of weighted distances - on Kemeni-Snell's classical median [10]

$$
\tilde{\mathbf{Q}}=\left[\tilde{a}_{n k}\right]_{N_{M S P M} \times N_{M S P M}} \in \arg \left\{\min _{i=1, K} \sum_{j=1}^{W} \alpha_{j} \cdot r_{\text {vidst }}\left(\mathbf{Q}_{j}, \mathbf{U}_{i}\right)\right\}
$$

where $\alpha_{j}$ is the factor showing competence of $j^{\text {th }}$ expert.

Factors $\left\{\alpha_{j}\right\}_{j=1}^{W}$ are, as a rule, rationed

$$
\sum_{j=}^{W} \alpha_{j}=1
$$

and

$$
\alpha_{j} \in(0 ; 1) \text { for all } j=\overline{1, W}
$$

that is, cases $\alpha_{j}=0$ and $\alpha_{j}=1$ are excluded (they are basically impossible, as they correspond to either absolutely incompetent experts, or only one expert, whose engagement into such large-scale procedure of evaluating all possible marketing strategies of personnel management by multitude does not make sense). However, experts involved frequently have approximately identical professional knowledge and experience; therefore, their competence is approximately accepted equal. Then they are taken to be equal to

$$
\alpha_{j}=\frac{1}{W} \quad \text { for all } \quad j=\overline{1, W}
$$

At the same time, formula (10) is only simplified in general it is possible "remove" factor $\alpha_{j}$ from it. Matrix, by which minimum weighted distance will be reached will not change because of it (the minimum weighted distance itself will change, but it is not of our concern).

After definition of the averaged matrix of pairwise comparisons by the formula (10), we define so-called priorities.

Priority of the $n^{\text {th }}$ marketing strategy of personnel management is calculated in two phases:

1. The common (unstandardized) value of priority of the $n^{\text {th }}$ marketing strategy of personnel management [9] is

$$
p_{n}=\left(\prod_{k=1}^{N_{M S P M}} \tilde{a}_{n k}\right)^{\frac{1}{N_{M S P M}}} \text { for all } n=\overline{1, N_{M S P M}}
$$

2. The standardized value of priority of the $n^{\text {th }}$ marketing strategy of personnel management [9] is 


$$
\tilde{p}_{n}=\frac{p_{n}}{\sum_{q=1}^{N_{\text {MSPM }}} p_{q}}
$$

for all $n=\overline{1, N_{M S P M}}$.

It is evident that standardized values of priorities (12) are interconnected

$$
\sum_{n=}^{N_{\text {MSPM }}} \tilde{p}_{n}=1
$$

so

$$
\tilde{p}_{n} \in(0 ; 1) \text { for all } n=\overline{1, N_{M S P M}} .
$$

The higher priority is, the more probable and expedient use of appropriate marketing strategy of personnel control is. Certainly, cases and are entirely excluded - at any circumstances are they possible, as only positive values appear in the formula (11).

Now, functional transition of the type (5) is built by selecting the best (optimum) marketing strategy of personnel management which is defined by simple conformity to that number $n^{*}$, which is

$$
n^{*} \in \arg \underset{n=1, N_{M S P M}}{\max } \tilde{p}_{n} .
$$

If there are several such numbers, then preference is given to the number of marketing strategy of personnel management, which grants greater value for function $M P_{\text {Parts }}\left(t_{\text {perem }}, k_{\text {inter }}\right)$ before solution of the task (3).

Let us note that the evaluation of coordination of the matrix of pair comparisons is extremely important. For consistency check, we calculate coordination index

$$
I_{u z g d d}=\frac{\lambda_{\max }-N_{M S P M}}{N_{M S P M}-1},
$$

where

$$
\lambda_{\max }=\sum_{n=1}^{N_{\text {MSPM }}} \sum_{k=1}^{N_{\text {MSPM M }}} \tilde{a}_{n k} \cdot \tilde{p}_{k}
$$

In the case of high consistency of the matrix the value $\lambda_{\max }$ is close enough to the common number of all possible marketing strategies of control $N_{M S P M}$. We further find conformity relation

$$
\rho_{u z g o d}=\frac{I_{u z g o d}}{I_{N_{M S P M}}},
$$

where $I_{N_{M S P M}}$ is an average random index for positive back-symmetric matrix of the format $N_{M S P M} \times N_{M S P M}$. Index $I_{N_{\text {MSPM }}}$ is taken from the known table of such indexes.

The expert opinions, in which $\rho_{u z g o d} \leq 0.1$, correspond to satisfying consistency of the matrix of pair comparisons. Then expert opinions in the form of the matrixes of pair comparisons $\left\{\mathbf{Q}_{j}\right\}_{j=1}^{W}$ are also considered consistent, and the matrix of pairwise comparisons is taken to be acceptable for making appropriate conclusions. One of such conclusions there is the list of priorities $\left\{\tilde{p}_{k}\right\}_{k=1}^{N_{\text {MSPM }}}$, where is the priority of the $k^{\text {th }}$ marketing strategy of personnel management. The more

is, the more rational and justified the $k^{\text {th }}$ marketing strategy is.

Marketing strategy with least priority, that is, strategy with the number $k_{0}$, which is defined from correlation

$$
k_{0} \in \arg \min _{n=1, N_{\text {MSPM }}} \tilde{p}_{n},
$$

is the most unprofitable (the worst). We will note again that there can be more than one of such numbers.

If the matrix turns out to be inconsistent, that is, will be $\rho_{u z g o d}>0.1$, then the expert opinions in the form of the matrixes of pair comparisons $\left\{\mathbf{Q}_{j}\right\}_{j=1}^{W}$ are also considered inconsistent. Then expert procedure should be repeated.

We will note that prioritization of marketing strategies of personnel management is quite expedient at machine-building enterprises. For example, if in the list of priorities it is obtained

$$
\tilde{p}_{5}>\tilde{p}_{3}>\tilde{p}_{9}>\tilde{p}_{6}>\ldots,
$$

but the fifth marketing strategy cannot be used (introduced) for the appropriate reasons or circumstances independent of an enterprise, then it is necessary to apply the third strategy. If the fifth and third strategies cannot be used simultaneously, so, it is necessary to apply the ninth marketing strategy of personnel management.

Therefore, the suggested economic and mathematical model is a logic embodiment of the matrix of mutual positioning of strategies of marketing and personnel management, and consequently it forms the basis for formation and implementation of scenario approach in machine-building enterprises' activities.

\section{Conclusions.}

1. The conceptual foundations of formation of marketing strategy of personnel management are justified, which are based on: definition of the content of personnel management and directions of its strategy; formation of the conception of holistic marketing with definition of the role of the personnel marketing and phasingout; analysis of socio-economic preconditions of application of marketing strategies of personnel management; analysis of the organization of personnel management at machine-building enterprises; research on components of formation of marketing strategies of personnel management of machine-building enterprises.

Application of economic and mathematical toolkit in this process allows solving an important task on formation and application of the databank of marketing strategies of personnel management and the computerizations of the process of making adequate managerial decisions.

2. The complex approach to formation of marketing strategy of personnel management is developed in view of the common and specific principles, which are aimed 
at realization of purposes and the tasks of management with the aid of the appropriate marketing toolkit. For realization of the suggested approach, the economic and mathematical model of mutual positioning of strategies of marketing and personnel management is developed and approved by the example of enterprises of the mechanical engineering sector of Ukraine. Results obtained during practical approval confirmed adequacy of economic and mathematical model and expediency of its application, which found reflection in the appropriate economic benefit. At the enterprises which applied the suggested approach, optimization of process of monitoring in the domain of marketing and personnel selection at the expense of elimination of duplicating information flows is observed.

3. Implementation of economic and mathematical model was performed by the matrix of mutual positioning of strategies of marketing and personnel management. The matrix is an effective tool of making adequate managerial decisions for achievement of desired results (economical, marketing, managerial, social, household ones). At the same time, mathematical problem solving enables with the aid of the appropriate software to simplify the process of making managerial decisions while selecting adequate to framework conditions, state of external and internal environment of the enterprise, marketing strategy of personnel management.

Research is performed within research work 4Б-2017 "Control of innovations in planning and marketing on the basis of marginal approach” (№ ДР 0117U001169).

\section{Reference.}

1. Valentina Ghinea Mihaela and Moroianu Mădălina, 2016. HR strategy - necessity or fad for business sustainability? Management şi Marketing, 11(2), pp. 458-469.

2. Nazarcu Herascu Daniela, Gadei Cristina Gina and Susanu Irina Olimpia, 2015. Integration of the freelancing in the marketing strategy of the organization. Risk in Contemporary Economy, 2(1), pp. 590-598.

3. Jacqueline Chimhanzi and Robert E. Morgan, 2005. Explanations from the marketing/human resources dyad for marketing strategy implementation effectiveness in service firms. Journal of Business Research, 58(6), pp. 787-796. DOI: 10.1016/j.jbusres.2003.11.003.

4. Chimhanzi, J., 2001. The impact of marketing/HR interactions on marketing strategy implementation. $E \mathbf{E}$ ropean Journal of Marketing, 38(1), pp. 73-98. DOI: 10.1108/03090560410511131.

5. Grohmann, O., 2015. HR Strategy. In: Zeuch M., eds., 2015. Dos and Don'ts in Human Resources Management. Berlin, Heidelberg: Springer Gabler, pp. 169-171. 6. Castro, C.L. and Malcolm, H., 2008. How the alignment of business strategy and HR strategy can impact performance. Journal of General Management, 33(4), pp. 13-34. DOI: 10.1177/030630700803300402.

7. Pashchuk, L., 2016. Marketing-based human resource management strategy development. Technology audit and production reserves, 5/4(31), pp. 33-38. DOI: 10.15587/2312-8372.2016.81474.

8. Kovalchuk, S., Kobets, D. and Dybchuk, L., 2016. Formation of a system approach to the optimization of marketing management at an enterprise. Eastern-European Journal of Enterprise Technologies. MATHEMATICS AND CYBERNETICS - APPLIED ASPECTS, 3/5(81), pp. 4-12.

9. Romanuke, V. V., 2016. Evolution of expert competences in estimating a finite set of objects by a given comparison scale via pairwise comparison matrices within the space of positive inverse-symmetric matrices. Herald of Khmelnytskyi national university. Technical sciences, 2, pp. 25-29.

10. Romanuke, V. V., 2016. A criterion of aggregating expert estimations into consensus pairwise comparison matrix by a given comparison scale within the corresponding space of positive inverse-symmetric matrices. Herald of Khmelnytskyi national university. Technical sciences, 1, pp. 78-84.

11. Romanuke, V. V., 2016. Algorithm of fast Kemeny consensus by searching over standard matrices distanced to the first ranking as the averaged expert ranking by minimal difference. Research Bulletin of NTUU "Kyiv Polytechnic Institute”, 1, pp. 50-57.

\section{Моделювання вибору стратегій маркетингового управління персоналом підприємства}

\section{С. В. Ковальчук, Д. Л. Кобець, С. М. Забурмеха}

Хмельницький національний університет, м. Хмельницький, Україна, e-mail: sveta_marketing@ukr.net

Мета. Розгляд теоретичних і науково-методичних положень та розроблення практичних рекомендацій щодо формування економіко-математичної моделі взаємного позиціонування стратегій маркетингу та управління персоналом підприємства.

Методика. Застосовані методи аналізу, синтезу, узагальнення, порівняння та математичного моделювання.

Результати. Втіленням економіко-математичної моделі є матриця взаємного позиціонування стратегій маркетингу та управління персоналом підприємства. Матриця є дієвим інструментом прийняття адекватних управлінських рішень задля досягнення бажаного результату (економічного, маркетингового, управлінського, соціального, господарського). Разом із тим, математичний розв'язок задачі дає можливість спростити процес прийняття управлінських рішень щодо вибору маркетингової стратегії управління персоналом, адекватної рамковим умовам, стану зовнішнього та внутрішнього середовищ підприємства, .

Наукова новизна. Розроблено комплексний підхід до формування маркетингової стратегії управління персоналом підприємства з урахуванням загальних і специфічних принципів, спрямованих на реалізацію цілей і завдань кадрового менеджменту. Для реалізації запропонованого підходу побудована та проведена апробація економіко-математичної моделі взаємного позиціонування стратегій маркетингу та управління персоналом підприєм- 
ства на прикладі підприємств машинобудівного комплексу України.

Практична значимість. Отримані у процесі апробації результати підтвердили адекватність економіко-математичної моделі та доцільність іiі застосування, що знайшло відображення у відповідному економічному ефекті. На підприємствах, котрі застосували запропонований підхід, спостерігається оптимізування процесу управління у сфері маркетингу та кадрової політики за рахунок усунення дублюючих інформаційних потоків.

Ключові слова: маркетингова стратегія, системний підхід, управління персоналом, машинобудівне підприємство

\section{Моделирование выбора стратегий маркетингового управления персоналом предприятия}

\section{С. В. Ковальчук, Д. Л. Кобец, Е. М. Забурмеха}

Хмельницкий национальный университет, г. Хмельницкий, Украина, e-mail: sveta_marketing@ukr.net

Цель. Рассмотрение теоретических и научно-методических положений и разработка практических рекомендаций по формированию экономико-математической модели взаимного позиционирования стратегий маркетинга и управления персоналом.

Методика. Применены методы анализа, синтеза, обобщения, сравнения и математического моделирования.

Результаты. Воплощением экономико-математической модели является матрица взаимного позиционирования стратегий маркетинга и управления персоналом. Матрица является действенным инструментом принятия адекватных управленческих решений для достижения желаемого результата (экономического, маркетингового, управленческого, социального, хозяйственного). Вместе с тем, математическое решение задачи дает возможность упростить процесс принятия управленческих решений по выбору маркетинговой стратегии управления персоналом, адекватной рамочным условиям, состоянию внешней и внутренней среды предприятия.

Научная новизна. Разработан комплексный подход к формированию маркетинговой стратегии управления персоналом с учетом общих и специфических принципов, направленных на реализацию целей и задач кадрового менеджмента. Для реализации предложенного подхода построена и апробирована экономико-математическая модель взаимного позиционирования стратегий маркетинга и управления персоналом на примере предприятий машиностроительного комплекса Украины.

Практическая значимость. Полученные в процессе апробации результаты подтвердили адекватность экономико-математической модели и целесообразность ее применения, что нашло отражение в соответствующем экономическом эффекте. На предприятиях, которые применили предложенный подход, наблюдается оптимизация процесса управления в сфере маркетинга и кадровой политики за счет устранения дублирующих информационных потоков.

Ключевые слова: маркетинговая стратегия, системный подход, управление персоналом, машиностроительное предприятие

Рекомендовано до публікації докт. екон. наук О. О. Орловим. Дата надходження рукопису 31.01.18. 